\title{
OVERCOMING INTERSPECIFIC POLLEN INCOMPATIBILITY THROUGH THE USE OF IONISING RADIATION
}

\author{
KAMLA KANT PANDEY \\ Genetics Unit, Grasslands Division, D.S.I.R., Palmerston North, New Zealand
}

Received 3.i.74

\section{Summary}

\begin{abstract}
Attempts to overcome interspecific incompatibility in Nicotiana by X-irradiation of male parents have shown a difference in response between a self-incompatible (S.I.) and a self-compatible (S.C.) species. Compatibility can be produced in the $S_{I}$ pollen of the former but not in the $S_{f}$ pollen of the latter

The observations suggest that interspecific $S$-gene determination may be gametophytic for the $S_{I}$ alleles but sporophytic in the case of the $S_{f}$ allele. This sporophytic determination of the $S_{f}$ allele occurs very early, possibly at the time of floral induction, or even earlier. Irradiation of floral buds, therefore, does not produce effective mutations, for by then the $S$-gene product is already laid down in the cytoplasm.

By analogy it is suggested that in species with a sporophytically determined intraspecific incompatibility system, the $S$-gene products may also be laid down very early. This is in accordance with recent cytochemical observations.

In $S_{I} S_{f}$ hybrids the difference in time and tissue of action between sporophytically active $S_{f}$ and gametophytically active $S_{I}$ may allow the two alleles to be expressed without interaction.
\end{abstract}

\section{INTRODUGTION}

INTERSPECIFIC pollen-style incompatibility between closely related species is controlled together with intraspecific incompatibility by alleles of the $S$ locus (Lewis and Crowe, 1958; Pandey, 1961, 1962a, b, 1964, 1968, 1969a). However, although the intraspecific system has been broken down by irradiation in a number of cases (Lewis, 1948, 1949, 1951, 1954a, $b$; Lewis and Crowe, 1954; Pandey, 1956, 1959, 1965, 1970; Brewbaker and Natarajan, 1960), similar techniques have so far failed to overcome interspecific incompatibility (Davies and Wall, 1961). Furthermore, compatibility has been achieved by irradiation only in species with the gametophytic system of self-incompatibility, there being no comparable report for species with a sporophytic incompatibility system.

It has been proposed (Pandey, 1973) that when a gametophytically self-incompatible species becomes self-compatible there is, in time, an erosion of the $S$-gene complex associated with a progressive sporophytic determination of $S$-gene elements. Thus, self-compatibility alleles in species with relatively long-established self-compatibility may all be sporophytically determined. If this hypothesis is correct, it leads to the prediction that irradiation of the pollen parent at flowering may produce $S$-gene mutations overcoming interspecific incompatibility in gametophytically self-incompatible species, but not in self-compatible species.

This prediction has been confirmed. In the present experiment it has been found possible to break down interspecific incompatibility by X-irradiating pollen parents of self-incompatible Nicotiana glauca $\left(S_{I} S_{I}\right)$. 
However, in contrast it has proved impossible to produce similar mutations in the pollen of $\mathcal{N}$. langsdorffi $\left(S_{f} S_{f}\right)$ in which self-compatibility has probably been relatively long established.

\section{Materials and methods}

The sources of seed and experimental conditions have been given previously (Pandey, 1969a, $b, 1973$ ). The following materials were used:

Irradiated pollen parents

$\mathcal{N}$. langsdorffi $\left(S_{f} S_{f}\right), 4$ plants.

$\mathcal{N}$. glauca $\left(S_{I} S_{I}\right), 3$ plants.

Emasculated female parents (usually multiplied by cuttings)

$\mathcal{N}$. alata $\left(S_{1} S_{F_{10}}\right), 2$ plants; $\left(S_{3} S_{F_{10}}\right), 2$ plants. These 4 plants were selected for short flower length to enable pollen of the smallerflowered species $\mathcal{N}$. langsdorffi $i$ to traverse the full length of the style without difficulty.

$\mathcal{N}$. alata hybrid $\left(S_{F 11} S_{F 11}\right), 2$ plants with smaller flowers extracted from the hybrids $\mathcal{N}$. langsdorffi $($ ㅇ $) \times \mathcal{N}$. alata $\left(\delta^{\star}\right)$ and tested for normal self- and cross-compatibility behaviour before use.

$S_{I}$ and $S_{F I}$ alleles both condition normal intraspecific incompatibility but are polymorphic with regard to $S_{f}$ pollen of $\mathcal{N}$. langsdorffi. Styles containing $S_{F I}$ alleles reject this pollen while styles containing only $S_{I}$ alleles accept it. Thus the above $6 \mathcal{N}$. alata and $\mathcal{N}$. alata hybrid plants are normally incompatible with $\mathcal{N}$. langsdorffi pollen.

$\mathcal{N}$. forgetiana $\left(S_{I} S_{I}\right), 2$ plants of a polymorphic line which normally rejects pollen of $\mathcal{N}$. langsdorffii (Pandey, 1969b).

$\mathcal{N}$. langsdorffi and $\mathcal{N}$. glauca inflorescences with a few buds at meiotic or tetrad stages but most at premeiotic, sporogenous, or presporogenous stages, were X-irradiated at $500 \mathrm{r}(210 \mathrm{KVP}, \mathrm{HVL} 1.7 \mathrm{~mm} \mathrm{cu}, 15 \mathrm{~mA}, 50 \mathrm{~cm}$ distance, dose rate $42.9 \mathrm{r} / \mathrm{m}$ ). As irradiated buds came to bloom their pollen was used on the stigmas of the female parents. The maximum radiation-induced pollen sterility was usually below 50 per cent. In order to prevent premature abscission and consequent loss of rare mutant seeds $\beta$-naphthoxy acetic acid ( 1 per cent in lanolin) was applied to the calyx of pollinated flowers (Lewis, 1948).

\section{Results AND Discussion}

Results of the pollinations are shown in table 1. Nine pollinations with irradiated $S_{I}$ pollen of one $\mathcal{N}$. glauca plant produced a total of 70 hybrid seedlings. The obtaining of a progeny from only one pair of parents probably indicates a specific genomic compatibility between these two individuals, failure in the other combinations possibly being due to zygotic abortion or poor seed development rather than to $S$-gene incompatibility. This is supported by the observation that when a compatible polymorphic line of $\mathcal{N}$. forgetiana was pollinated with unirradiated $\mathcal{N}$. glauca pollen, viable seedlings were produced only when $\mathcal{N}$. glauca $\mathrm{Pl}$. 2 was used. Seeds obtained from pollen of $\mathcal{N}$. glauca $\mathrm{P}$. 1 gave seedlings which collapsed soon after germination. 
In contrast to the results obtained with $\mathcal{N}$. glauca pollen, no hybrids were produced in any of the combinations involving irradiated $S_{f}$ pollen of $\mathcal{N}$. langsdorffi. This failure represents true $S$-gene incompatibility since fully viable hybrid seeds can be produced if compatible polymorphic forms of the female parents $\mathcal{N}$. alata and $\mathcal{N}$. forgetiana are used.

The breakdown of incompatibility in irradiated $\mathcal{N}$. glauca pollen is believed to be due to mutation in the $S$ complex rather than to irradiation effects on cytoplasmic constituents. Firstly, the incompatibility in the $\mathcal{N}$. forgetiana $\times \mathcal{N}$. glauca cross is expressed in the stigma, or close to the stigma in the style, and hence cannot be considered as weak incompatibility which could be easily overcome in this manner. The similar but much more extensive experiments with the $\mathcal{N}$. langsdorffi pollen consistently failed to

TABLE I

Results of pollinations with irradiated pollen of $\mathrm{N}$. langsdorffii and $\mathrm{N}$. glauca

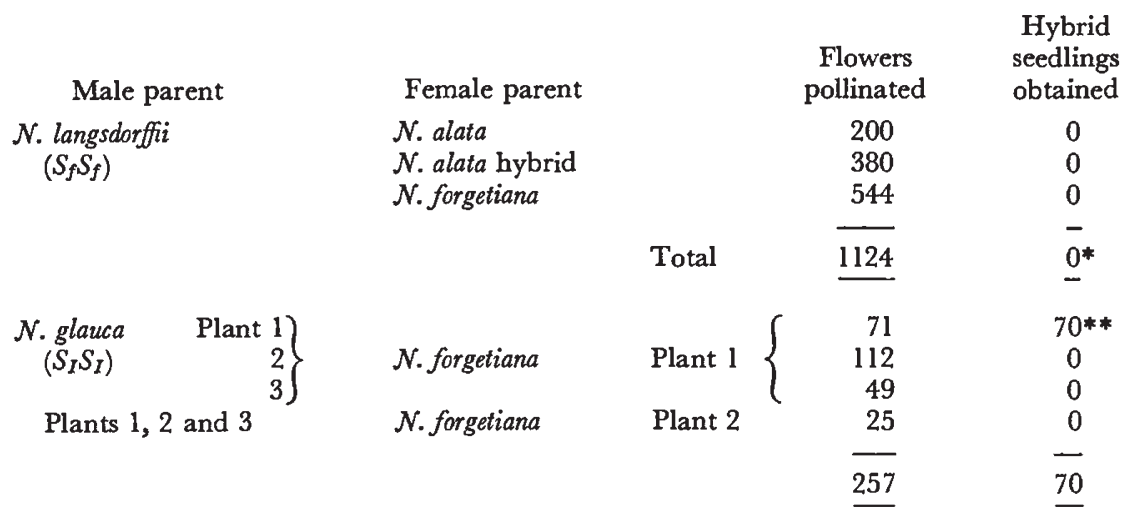

* A number of maternal $S$-homozygous parthenogenetic diploids were recovered from these combinations (Pandey, 1974).

** Recovered from a total of 9 successful pollinations.

produce any hybrid seed, although here in at least one combination $(\mathcal{N}$. forgetiana $\mathrm{Pl}$. $2 \times \mathcal{N}$. langsdorffi) normal incompatible pollen tubes reached almost half the length of the style. Secondly, the dose was too small to affect cytoplasmic constituents sufficiently to overcome a strong and rapid incompatibility reaction of the type shown in $\mathcal{N}$. forgetiana $\times \mathcal{N}$. glauca crosses. Thirdly, the changes observed were apparently limited to occasional random flowers. Unfortunately, owing to a high degree of sterility it has not been possible to directly test the pollen of the irradiation-induced $\mathcal{N}$. forgetiana $\times \mathcal{N}$. glauca hybrids for $S$-gene mutations. This means that the mutational basis of the change cannot be verified beyond doubt.

The results show that $S_{f}$ pollen from a self-compatible species and $S_{I}$ pollen from a related self-incompatible species differ in the response to irradiation of their interspecific reaction. It is believed that effective mutation of the $S$ complex can be induced only by irradiation before the gene products which determine incompatibility behaviour are laid down in the cytoplasm. If $S$-gene determination is gametophytic, as in $S_{I}$ pollen of $\mathcal{N}$. glauca, then irradiation at any time prior to this stage should result in mutation. The earlier in anther development the mutation occurs, the 
larger will be the final sector of mutant tissue, and the greater the number of hybrid seeds which the use of such an anther might be expected to produce. However, this will be realised only if each flower is pollinated with all the pollen of a single anther. Owing to large variability in the amount of pollen between individual anthers in irradiated flowers, this procedure was not strictly practicable. Hence, the seed-set results can only be regarded as indicative. Nevertheless, a pattern of this type is shown in table 2 by the time sequence and seed set data for the 9 successful pollinations with irradiated $\mathcal{N}$. glauca pollen. If, on the other hand, $S$-gene action is sporophytic and occurs early in floral development, irradiation after this time will be ineffective. The results are consistent with gametophytic $S$-gene determination in $\mathcal{N}$. glauca, but suggest that in $\mathcal{N}$. langsdorffi the interspecific incompatibility conditioned by the $S_{f}$ allele is sporophytically determined and occurs very early, possibly with floral induction or even earlier.

This difference in the time and tissue of action of $S_{I}$ and $S_{f}$ alleles gives a more logical explanation for the lack of allelic interaction at the primary gene

TABLE 2

Pollination time and seed set in the combination $\mathrm{N}$. forgetiana (female Plant 1) $\times \mathrm{N}$. glauca (Plant 1)

$\begin{array}{cccc}\text { Buds irradiated late } & \begin{array}{c}\text { Days from irradiation } \\ \text { to pollen maturation }\end{array} & \begin{array}{c}\text { No. of } \\ \text { pods }\end{array} & \begin{array}{c}\text { Mean seeds } \\ \text { per pod }\end{array} \\ \begin{array}{c}\text { in development } \\ \text { Buds irradiated early } \\ \text { in development }\end{array} & 16-19 & 6 & 52 \\ & 33-41 & 3 & 81\end{array}$

action phase in $S_{I} S_{f}$ hybrids of $\mathcal{N}$. alata $\times \mathcal{N}$. langsdorffi and $\mathcal{N}$. forgetiana $\times$ $\mathcal{N}$. langsdorffi observed by Pandey (1964, and unpublished). All pollen have the $S_{f}$ specificity laid down sporophytically. However, 50 per cent of grains carry the $S_{I}$ allele which is independently and gametophytically expressed to render this half of the pollen self-incompatible. A similar situation has been found in a strain of $\mathcal{N}$. glauca where self-compatibility and self-incompatibility alleles occur in the same plant (Pandey, 1973).

If the interspecific reaction of self-compatibility alleles is sporophytically determined and gene action occurs very early in development; it seems reasonable to expect similarly early action of both inter- and intraspecific components in species with sporophytic systems of intraspecific incompatibility. In such cases the $S$-gene products would be already laid down in the primordial anther tissues, and in particular may later be deposited in the pollen exine from the tapetum. This is in agreement with recent observations on the location and derivation of "pollen recognition substances" involved in inter- and intraspecific sporophytic incompatibility (J. HeslopHarrison, 1967, 1971; Knox and J. Heslop-Harrison, 1969; Knox, Willing and Pryor, 1972; J. Heslop-Harrison, Y. Heslop-Harrison, Knox and Howlett, 1973; Knox, 1973).

The present observations show that ionising radiation may have a practical application in achieving interspecific hybridisation where the parents are genomically compatible and a gametophytically self-incompatible species can be used as the irradiated male parent. Previous unsuccessful attempts 
to achieve interspecific hybridisation may in certain cases be attributed to failure to fulfill these conditions.

Further irradiation experiments of this type may also assist in clarifying physiological and evolutionary aspects of $S$-gene expression.

Acknowledgments.- - I am indebted to Mr R. J. Trott, Physicist at the Palmerston North Hospital, for his help and co-operation in the irradiation of the material. I thank Mr G. B. Petterson for expert technical assistance.

\section{RefERENGes}

BRewbaker, J. L., AND natarajan, A. T. 1960. Centric fragments and pollen-part mutation of incompatibility alleles in Petunia. Genetics, 45, 699-704.

DAVIES, D. R., AND WALL, E. T. 1961. Gamma radiation and interspecific incompatibility in plants. In Effects of Ionizing Radiation on Seeds, IAEA, Vienna, 83-101.

HeSLOP-HARRISON, J. 1967. Ribosome sites and $S$ gene action. Nature, 218, 90-91.

HESLOP-HARRISON, J. 1971. Sporopollenin in the biological context. In Sporopollenin, ed. J. Brooks, P. R. Grant, M. Muir, P. van Gjizel, and G. Shaw. London, Academic Press.

HESLOP-HARRISON, J., HESLOP-HARRISON, Y., KNOX, R. B., AND hOWLETT, B. 1973. Pollenwall proteins: "Gametophytic" and "Sporophytic" fractions in the pollen walls of the Malvaceae. Ann. Bot., 37, 403-412.

knox, R. B. 1973. Pollen wall proteins: Pollen-stigma interactions in ragweed and Cosmos (Compositae). 7. Cell Sci., 12, 421-443.

KNOX, R. B., HESLOP-HARRISON, J. 1969. Cytochemical localization of enzymes in the wall of the pollen grain. Nature, 223, 92-94.

KNOX, R. B., WILLING, R. R., AND PRYOR, L. D. 1972. Interspecific hybridization in poplars using recognition pollen. Silvae Genetica, 21, 3-4.

LEWLS, D. 1948. Structure of the incompatibility gene. I. Spontaneous mutation rate. Heredity, 2, 219-236.

LEwIS, D. 1949. Structure of the incompatibility gene. II. Induced mutation rate. Heredity, 3, 339-355.

LEws, D. 1951. Structure of the incompatibility gene. III. Types of spontaneous and induced mutation. Heredity, 5, 399-414.

LEWIS, D. 1954a. Comparative incompatibility in angiosperms and fungi. Adv. Genet., 6, 235-285.

LEWIS, D. 1954b. Incompatibility in relation to physiology, genetics and evolutionary taxonomy. Proc. 8th Intern. Bot. Congr., Sec. 10, 124-132.

LEWIS, D., AND CROWE, L. K. 1954. Structure of the incompatibility gene. IV. Types of mutations in Prunus avium L. Heredity, 8, 357-363.

LEWIS, D., AND CROWE, L. K. 1958. Unilateral interspecific incompatibility in flowering plants. Heredity, 12, 233-256.

PANDEY, K. K. 1956. Mutations of self-incompatibility alleles in Trifolium pratense and T. repens. Genetics, 41, 327-343.

PANDEY, K. K. 1959. Mutation of the self-incompatibility gene $(S)$ and pseudo-compatibility in angiosperms. Lloydia, 22, 222-234.

PANDEY, K. K. 1961. $S$ allele mutations and components of the $S$ gene. Heredity, 16, 239.

PANDEY, K. K. 1962a. Interspecific incompatibility in Solanum species. Am. $\mathcal{J}$. Bot., 49, $874-882$.

PANDEY, K. K. 1962b. A theory of $S$ gene structure. Nature, 196, 236-238.

PANDEY, K. K. 1964. Elements of the $S$-gene complex. I. The $S_{F I}$ alleles in Nicotiana. Genet. Res., Camb., 5, 397-409.

PANDEY, K. K. 1965. Centric chromosome fragments and pollen-part mutation of the incompatibility gene in Nicotiana alata. Nature, 206, 792-795.

PANDEY, K. K. 1968. Compatibility relationships in flowering plants: Role of the $S$-gene complex. Amer. Nat., 102, 475-489.

PANDEY, K. K. 1969a. Elements of the $S$-gene complex. IV. $S$-allele polymorphism in Nicotiana species. Heredity, 24, 601-619. 
PANDEY, K. K. 1969b. Elements of the $S$-gene complex. V. Interspecific cross-compatibility relationships and theory of the evolution of the $S$ complex. Genetica, 40, 447-474.

PANDEY, K. K. 1970. Elements of the S-gene complex. VI. Mutations of the selfincompatibility gene, pseudo-compatibility and origin of new self-incompatibility alleles. Genetica, 41, 477-516.

PANDEY, K. K. 1973. Phases in the $S$-gene expression, and $S$-allele interaction in the control of interspecific incompatibility. Heredity, 31,381-400.

PANDEY, K. K. 1974. Elimination of heterozygosity and efficiency of genetic systems Theoret. and Appl. Genet., 44, 199-205. 